\title{
Ağırlık Yönetiminde Omega-3 Çoklu Doymamış Yağ Asitlerinin Rolü
}

\author{
The Role of Omega-3 Polyunsaturated Fatty Acids in Weight Management
}

\section{Ramazan Mert Atan ${ }^{1}$, Nihal Zekiye Erdem ${ }^{2}$}

Geliş tarihi/Received: 12.05.2021 • Kabul tarihi/Accepted: 09.08.2021

\section{ÖZET}

Obezite; vücutta anormal veya aşırı yağ birikimi olarak tanımlanır ve pandemik bir hastalık olarak kabul edilir. Birçok metabolik hastalığın oluşmasına neden olan obezite, aynı zamanda ülkelerin sağlık maliyetlerini de ciddi düzeylerde artırmaktadır. Bütüncül olarak yaklaşıldığında kalıcı tedavi çözümlerinin elzem olduğu görülmektedir. Tıbbi beslenme tedavisi, egzersiz ve davranış değişikliği kombinasyonunun en etkili tedavi yöntemi olduğu bilinmektedir. Bu yöntemlere ek olarak omega-3 çoklu doymamış yağ asitlerinin vücut ağırlık kaybı üzerinde etkili olabileceği düşünülmektedir. Linoleik asit ve $a$-linolenik asit sentezi insan vücudunda gerçekleştirilemediği için besinler ile alınması gereklidir. Özellikle eikosapentaenoik asit (EPA) ve dokosaheksaenoik asit (DHA) gibi omega-3 çoklu doymamış yağ asitlerinin, farklı metabolik değişiklikler yoluyla vücut ağırlık kaybı üzerinde etkili olabileceği belirtilmektedir. Ancak, yapılan araştırmalar incelendiğinde omega-3 çoklu doymamış yağ asitlerinin bu etkileri belirsizliğini korumaktadır. Bu derleme yazının amacı; vücut ağırlık yönetiminde omega-3 çoklu doymamış yağ asitlerinin rolü ve önerilen etki mekanizmaları hakkında literatürde yer alan güncel bilgilerin sunulmasıdır.

Anahtar kelimeler: Obezite, omega-3, ağtrlık kaybı

\begin{abstract}
Obesity is defined as abnormal or excessive fat accumulation in the body and is considered a pandemic disease. Obesity, which causes many metabolic diseases, also increases the health costs of countries seriously. It is seen that permanent treatment is essential when approached holistically. The combination of medical nutrition therapy, exercise, and behavior modification is known to be the most effective treatment method. In addition to these methods, omega-3 polyunsaturated fatty acids are thought to be effective on weight loss. Since linoleic acid and a-linolenic acid synthesis cannot be performed in the human body, they must be provided with foods. In particular, it is suggested that omega-3 polyunsaturated fatty acids such as eicosapentaenoic acid (EPA) and docosahexaenoic acid (DHA) may affect weight loss through different metabolic changes. However, these effects of omega-3 polyunsaturated fatty acids are still unclear when the researches are examined. The purpose of this review article is to present current information about the role of omega-3 polyunsaturated fatty acids in weight management and their proposed effect mechanisms in the literature.
\end{abstract}

Keywords: Obesity, omega-3, weight loss

1. İletişim/Correspondence: Bandırma Onyedi Eylül Üniversitesi, Sağlık Bilimleri Fakültesi, Beslenme ve Diyetetik Bölümü, Balıkesir, Türkiye

E-posta: dyt.mertatan@gmail.com • ๑ https://orcid.org/0000-0003-4608-605X
2. İstanbul Medipol Üniversitesi, Sağlık Bilimleri Yüksekokulu, Beslenme ve Diyetetik Bölümü, İstanbul, Türkiye • • ำ https://orcid.org/0000-0001-7046-9515 


\section{GİRIŞ}

Vücutta sağlık açısından risk oluşturacak ölçüde anormal veya aşırı yağ birikimi olarak tanımlanan obezite, dünya çapında önemli bir sağlık sorunudur. Son yıllarda yetişkinlerde ve çocuklardaki prevalansı ciddi düzeyde artmıştır (1). Dünya Sağlık Örgütü’nün (WHO) 2016 yılı verilerine göre; dünyadaki 18 yaş ve üzeri yetişkin nüfusunun yaklaşık olarak \%39’u fazla kilolu, \%13'ü obezdir (2). Ülkemizdeki son verilere göre ise 15 yaş ve üzeri bireylerin \%34'ünün fazla kilolu, \%31.5'inin obez olduğu saptanmıştır (3). Küresel boyutta görülen bu belirgin artıştan dolayı obezite, pandemik bir hastalık olarak kabul edilmektedir. Ayrıca koroner kalp hastalığı, Tip 2 Diabetes Mellitus (T2DM), metabolik sendrom ve bazı kanser türlerinin morbidite risklerini artırdığ için tedavisi elzemdir. Oluşma nedenleri arasında genetiğin yanı sıra, sağlıksız beslenme ve hareketsizlik gibi hem çevresel hem de davranışsal faktörler rol oynamaktadır (4). Özellikle yaşam tarzı değişiklikleri primer tedavi seçenekleri arasında yer almaktadır. Diğer tedavi seçenekleri arasında ise farmasötikler, cerrahi yöntemler ve besin destekleri bulunur. Bunlara rağmen obezite prevalansı artmaya devam etmektedir (1).

Diyetteki yağ asitlerinin türü ve oranı vücut fizyolojisini önemli düzeylerde etkilemektedir. Buna göre doymuş ve trans yağ asitlerinin sağlığa zararlı etkilerinin olduğu ve bu yağ asitleri yerine daha çok tekli doymamış yağ asitleri (MUFA) ile çoklu doymamış yağ asitleri (PUFA)'nin tercih edilmesi gerektiği vurgulanmaktadır (1). Diyette EPA veya DHA gibi omega-3 (n-3) PUFA'lardan zengin deniz ürünlerinin ve balık yağı desteğinin yer alması; kardiyoprotektif, anti-inflamatuvar ve hipotrigliseridemik özellikler gösterebileceği bildirilmektedir (1,5,6). Ayrıca, bazı çalışmalarda n-3 PUFA'ların vücut ağırlık kaybı üzerinde etkili olabileceği ileri sürülmektedir $(7,8)$. Ancak, bu bulguların aksini gösteren çalışmalarda mevcuttur $(9,10)$. Bu derleme makalede amaç; vücut ağırlık yönetiminde n-3 PUFA'ların rolü ve önerilen etki mekanizmaları hakkında literatürde yer alan güncel bilgilerin sunulmasıdır.
Omega-3 PUFA'ların Kaynakları, Sentezleri ve Metabolizmaları

İnsan vücudunda birçok yağ asidi sentezlenebilmekte olup, linoleik asit (LA) (18:2 n-6) ve a-linolenik asit (ALA) (18:3 n-3) sentezi için gerekli olan desatüraz enzimleri mevcut değildir. Elzem yağ asitleri olarak bilinen bu yağ asitlerinden LA, insan vücudundaki metabolizması sonucu araşidonik aside dönüşebilmektedir. Bunun yanı sıra vücutta ALA'dan EPA (20:5 n-3), dokosapentaenoik asit (DPA; 22:5 n-3) ve DHA (22:6 n-3) oluşturulabilmektedir. Elzem yăg asitlerinin vücuttaki metabolik dönüşümleri Şekil 1'de gösterilmiştir (11). Her iki dönüşümde de rol oynayan $\Delta 5$ ve $\Delta 6$ desatüraz ile elongaz enzimleri için n-6 ve $n-3$ yağ asitleri arasında rekabet vardır. Normal koşullar altında desatüraz enzimleri ALA'yı LA'ya tercih ederler. Bununla birlikte fazla miktarlarda LA alımı, ALA'nın desatürasyonunu ve uzamasını engellemektedir (12). Ayrıca, ALA'nın EPA ve DPA'ya dönüşüm oranlarının düşük olduğu ve DHA sentezinin çok az olduğu veya hiç olmadığı bildirilmektedir. Bu nedenle EPA ve DHA'nın diyette yer alması elzemdir (1). Ayçiçeği, mısır, kanola gibi bitkisel yağlar LA içeriği bakımından zengin iken, daha az miktarlarda ALA içermektedirler. Bunun yanı sıra yeşil yapraklı sebzelerde, keten (Linum usitatissimum) ve chia (Salvia hispanica) tohumlarında ALA bulunmaktadır. Somon, ton balığı, ringa balığı gibi balıklar ve diğer deniz ürünleri ise EPA ve DHA bakımından zengin n-3 PUFA kaynaklarıdır (12). Ek olarak, araşidonik asidin tahilla beslenen hayvanların etlerinde, süt ürünlerinde ve yumurtalarında daha fazla olduğu bildirilmiştir (11).

Kronik hastalıklar üzerinde n-3 PUFA'ların olumlu etkilerinin olduğuna dair bilimsel araştırmalar olmasına rağmen, optimal bir doz belirlenememiştir $(5,13)$. Amerika Gıda ve İlaç Dairesi'ne (Food and Drug Administration-FDA) göre 3 g/gün'e kadar olan alımların güvenli olduğu ve besin destekleri ile alınan miktarın 2 g/gün'den fazla olmaması gerektiği kabul edilmektedir (14). Ancak, Avrupa 
n-6 PUFA

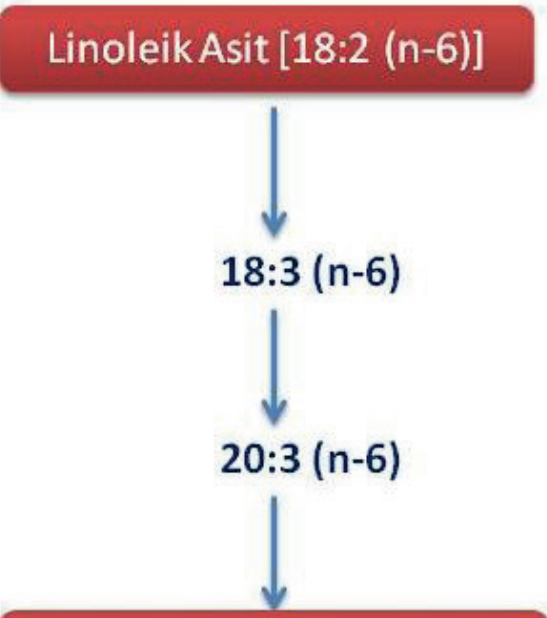

Araşidonik Asit [20:4 (n-6)]
$\Delta 6$ desatüraz

elongaz

$\Delta 5$ desatüraz

$\Delta 4$ desatüraz n-3 PUFA

\section{$\alpha$-Linolenik Asit $[18: 3(\mathrm{n}-3)]$}

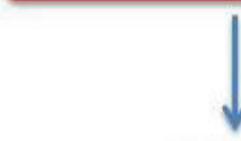

$18: 4(n-3)$

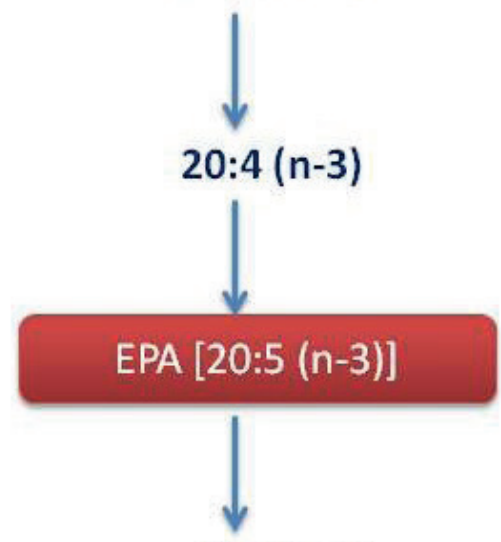

$22: 5(n-3)$

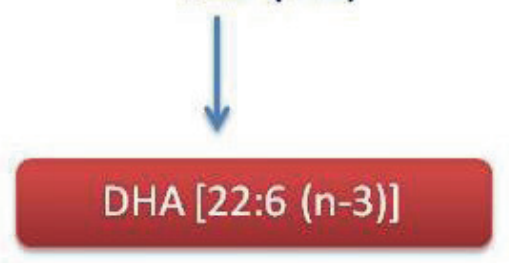

Şekil 1. Elzem yağ asitlerinin vücuttaki metabolik dönüşümleri (11)

DHA: Dokosaheksaenoik asit, EPA: Eikosapentaenoik asit, PUFA: Çoklu doymamış yağ asidi

Gıda Güvenliği Otoritesi (European Food Safety Authority -EFSA) tarafindan 5-6 g/gün'e kadar olan alımlarda da herhangi bir yan etkiye neden olmadığı rapor edilmiştir (15). Amerikalılar için Beslenme Rehberinde günde ortalama $250 \mathrm{mg}$ EPA ve DHA alımını sağlayacak miktarda haftalık deniz ürünlerinin tüketimi önerilmektedir (16). Ayrıca, n-3 PUFA'ların emülsifikasyonu ile biyoyararlanımlarının iyileştirilebileceği bildirilmektedir. Emülsifiye edilmiş n-3 PUFA'lar pankreatik lipaz ve kolipaz enzimleri tarafından daha etkili bir şekilde sindirilmekte olup, enterositlere taşınmaları daha kolay olmaktadır (17).

\section{Diyetteki Omega-6 ve Omega-3 PUFA Dengesinin Önemi}

Memeli hücrelerinde n-6 ve n-3 PUFA'lar birbirlerine dönüşemezler ve bu yağ asitlerinin metabolik ve fonksiyonel özellikleri birbirlerinden farklıdır. Genel olarak zit fizyolojik etkilere sahip olduklarından dolayı diyetteki dengeleri önem kazanmaktadır. Temelde araşidonik asit ve EPA'dan üretilen eikosanoidler, biyoaktif sinyal lipidleri olarak bilinmektedir. Araşidonik asitten siklooksijenaz (COX) enzimi aracılığıyla prostaglandin E2 (PGE2), prostaglandin I2 (PGI2), tromboksan A2 (TXA2) ve lipoksijenaz (LOX) enzimi aracılığıyla lökotrien-4 (LT-4) serisi oluşturulurken, EPA'dan ise aynı enzimler aracılığıyla PGE3, PGI3, TXA3 ve LT-5 serisi sentezlenmektedir (12). Araşidonik asitten elde edilen eikosanoidlerin fazla miktarlarda sentezlenmeleri halinde tromboz ve aterom meydana gelmektedir. Ayrıca, bu eikosanoidler pro-inflamatuvar etki göstermektedirler. Eikosapentaenoik asitten elde edilenler ise anti-inflamatuvar etkiye sahiptirler. Bu 
nedenle diyette n-6/n-3 oranının artması; ateroskleroz, T2DM ve obezite prevalansinin artmasina neden olmaktadır (11). Yaşam boyu homeostaz ve normal bir gelişim için önerilen n-6/n-3 oranı 1/1-2/1'dir (12). Günümüzdeki "Batı tipi diyetlerde” ise 10/1-20/1 gibi daha yüksek n-6/n-3 oranları mevcuttur (1). Ancak, paleolitik dönemde yaşayan insanların diyetleri incelendiğinde; n-6 ve n-3 yağ asitleri alımlarının neredeyse birbirlerine eşit olduğu bildirilmektedir. Günümüzde üretilen hayvan yemlerinin içeriğinde bulunan n-3 PUFA miktarlarının azalması sonucu hayvan etlerinin, yumurtaların ve hatta balıkların n-3 PUFA miktarlarının azaldığı saptanmıştır (11).

\section{Omega-3 PUFA'ların Vücut Ağırlık Kaybına Etkisi}

Balık ve diğer deniz ürünlerinin tüketimi ile vücuda alınan n-3 PUFA miktarları, popülasyonlar arasında farklılık göstermektedir. Özellikle kutup bölgesi ve Japonya'da yaşayan bireyler 4-5 g/gün kadar n-3 PUFA alırken, Avrupa ve Kuzey Amerika'da yaşayanların alımları ise $0.25 \mathrm{~g} /$ gün kadardır. Eskimo ve Japon popülasyonlarının daha sağlıklı bir metabolik profile sahip olmalarının, plazma n-3 PUFA düzeylerinin daha yüksek olmasından kaynaklandığı düşünülmektedir (1).

Fazla kilolu ve obez bireylerde n-3 PUFA alımlarının vücut ağırlık kaybı üzerindeki etkileri hakkında belirsizlik söz konusudur. Farklı besin gruplarının vücut ağırlığı üzerindeki etkilerini inceleyen bir sistematik derleme ve meta-analiz çalışmasına göre, günde 1 porsiyon balık tüketiminin abdominal obezite riskinde azalma ile ilişkili olduğu tespit edilmiştir (18). Özellikle enerji kısıtlaması ile n-3 PUFA desteğinin, vücut ağırlık kaybı üzerinde daha etkili olduğunu bildiren çalışmalar mevcuttur $(7,8)$. Keshavarz et al. (8) fazla kilolu ve obez kadınlara 12 hafta boyunca enerji kısıtlaması ile birlikte 1.08 g/gün EPA + 720 mg/ gün DHA desteği uygulanmasının, plasebo grubuna $(1.16 \pm 2.7 \mathrm{~kg}$ vücut ağırlık kaybı) kıyasla anlamlı olarak daha fazla $(3.07 \pm 3.4 \mathrm{~kg})$ vücut ağırlık kaybı oluşturduğunu belirtmişlerdir. Enerji kısıtlaması ve n-3 PUFA kombinasyonunun vücut ağırlık kaybının yanı sıra, insülin direnci ve trigliserid (TG) düzeyleri gibi metabolik parametreler üzerinde de olumlu etkilerinin olduğu bildirilmektedir (6). Non-alkolik yağlı karaciğer hastalığı (NAYKH) üzerine yapılan 22 randomize kontrollü çalışmanın değerlendirildiği bir meta-analiz çalışmasında, farklı miktar ve sürelerde uygulanan n-3 PUFA desteğinin özellikle abdominal ultrasonografi ile belirlenen karaciğer yağlanmasında iyileştirici etkilerinin olduğu, toplam kolesterol ve TG düzeylerini düşürdüğü (sırasıyla ortalama fark: -7.82 ve -28.57), yüksek dansiteli lipoprotein (HDL-K) düzeylerini ise artırdığı (ortalama fark: 3.55) gösterilmiştir. Ayrıca, n-3 PUFA desteğinin kontrol grubuna göre beden kütle indeksini (BKI) daha fazla düşürdüğü (ortalama fark: -0.46) tespit edilmiştir (19). Bazı çalışmalarda ise farklı kaynaklardan alınan n-3 PUFA'ların, vücut ağırlık kaybı üzerinde herhangi bir farklı etkilerinin olup olmadığı incelenmiştir. Buna göre n-3 PUFA alımlarının balık tüketimi veya balık yağı kapsülü ile olması, vücut ağırlık kaybı üzerinde herhangi bir farklılığa sebep olmamıştır $(7,20)$. Ancak, haftada 3 kere 150 g yağlı balık tüketimi ile 8 hafta boyunca alınan n-3 PUFA'ların TG düzeylerini düşürmede daha etkili olduğu belirtilmiştir (20).

Omega-3 PUFA'ların vücut ağırlık kaybı üzerinde herhangi bir değişikliğe neden olmadığını bildiren çalışmalar da mevcuttur $(9,10)$. Yetişkin obez bireylerde yapılan plasebo kontrollü bir çalışmada, 12 ay boyunca enerji kısıtlaması ile birlikte haftada $180 \mathrm{~g}$ yağlı balık tüketiminin veya yağlı balık tüketimine ek olarak 420 mg/gün EPA + 210 mg/gün DHA desteğinin ağırlık kaybını sağladığı, ancak kontrol grubundan farklı sonuçlara neden olmadığı gösterilmiştir (10). Fazla kilolu ve obez bireylere enerji kısitlaması olmadan 12 hafta boyunca 2.8 g/gün DHA desteği uygulanan bir çalışmada ise vücut ağırlık kaybı ve vücut kompozisyonu değişiminin istatistiksel olarak anlamlı olmadığı tespit edilmiştir (21). Farklı miktar ve sürelerde n-3 PUFA desteği uygulanmış randomize kontrollü çalışmaları değerlendiren iki farklı metaanaliz çalışmasında da n-3 PUFA desteğinin vücut ağırlık kaybı üzerine etkisi gösterilememiş, ancak abdominal yağ dokusu, bel çevresi ve TG düzeyinin düşmesi üzerine etkili olduğu rapor edilmiştir. Her iki 
meta-analiz çalışmasında da vurgulanan ana sonuç; n-3 PUFA'ların vücut ağırlık kaybı üzerindeki etkileri hakkında kesin sonuçlara varabilmek için daha büyük ölçekli ve uzun vadeli randomize kontrollü çalışmaların yapılmasıdır (22,23). Ayrıca, n-3 PUFA'ların lipid profili ve vücut kompozisyonunda meydana getirdiği değişiklikler sayesinde kardiyovasküler hastalıklardan (KVH) koruyucu olma potansiyeli taşıdığı düşünülmektedir (12).

Klinik çalışmalarda görülen bu çelişkili sonuçların birkaç nedeni bulunmaktadır. Bunlar arasında; n-3 PUFA desteği dozlarının, zamanlamalarının ve sürelerinin farklı olması, çalışma popülasyonunun demografik özelliklerinin ve diyetlerindeki n-6/n-3 oranlarının dikkate alınmaması, n-3 PUFA alımlarının belirlenmesinde subjektif yöntemlerin kullanılması yer almaktadır (11). Özellikle çalışmalarda omega-3 indeksinin kullanılması, orta vadeli (yaklaşık 3 ay) n-3 PUFA alımlarını yansıtmaktadır. Bu yöntem besin tüketim sıklığıyla elde edilen subjektif yöntemlere kıyasla daha kesin sonuçların elde edilmesini sağlar. Omega-3 indeksi; eritrositlerin hücre membran lipidlerindeki EPA ve DHA oranını göstermektedir. $\mathrm{Bu}$ yöntem ile yapılan çalışmalarda daha düşük bir omega-3 indeksinin; daha yüksek BKİ ve bel çevresi ile ilişkili olduğu saptanmıştır (24,25). Bunların dışında, genetik faktörlerin n-6 ve n-3 yağ asitleri metabolizmasındaki desatüraz enzimlerini etkilediği belirtilmektedir. İnsanlarda iki farklı desatüraz enzimi haplotipi (A ve D haplotipi) olduğu ve bu haplotiplerin n-6 ve n-3 yağ asitleri metabolizmasını etkilediği tespit edilmiştir (26).

\section{Omega-3 PUFA'ların Vücut Ağırlı Kaybı Oluşturmadaki Olası Etki Mekanizmaları}

Omega-3 PUFA'ların vücut ağırlı kaybı üzerindeki etkileri hakkında birçok metabolik değişiklik mekanizmalarının rolü olduğu düşünülmektedir. Bunlar arasında; karbonhidrat ve lipid metabolizmalarını etkilemesi, yă̆ asidi oksidasyonunu ve enerji harcamasını artırması, iştah düzeyini azaltması gibi değişiklikler yer almaktadır (Şekil 2) $(1,4,11)$.
Obez bireylerin çoğunda leptin direncinden kaynaklandığı düşünülen yüksek plazma leptin düzeyleri mevcuttur. Vücut ağırlık kaybıyla birlikte plazma leptin düzeylerinde de düşüşler meydana gelmektedir. Bir süre sonra bu durumun iştah düzeylerini artırmasına, daha düşükbir metabolikhıza ve sonuç olarak tekrardan vücut ağırlık kazanımına yol açtığı düşünülmektedir (1). Obez kadınlar üzerinde yapılan bir çalışmada, vücut ağırlık kaybının 10 hafta boyunca 1.3 g/gün EPA ile desteklenmesi plazma leptin düzeylerindeki azalmayı hafiflettiği ve vücut ağırlık kaybının daha istikrarlı bir şekilde sürdürülmesine katkı sağladığı tespit edilmiştir (27). Ek olarak, deney hayvanları ve adiposit hücrelerinde yapılan çalışmalarda da EPA'nın leptin üretimini istatistiksel olarak anlamlı düzeylerde artırdığı saptanmıştır $(28,29)$. Ancak, bazı çalışmalarda ise bu bulgular desteklenmemiştir $(4,30)$. Leptin dışında n-3 PUFA'lar, ince bağırsaktan sentezlenen ve anoreksijenik bir peptid hormonu olan kolesistokinin sekresyonunu etkileyebileceği düşünülmektedir. Omega-3 PUFA'lar yağ asidi bağlayıcı protein-4 (FFAR-4) için agonist olarak davranirlar ve FFAR-4'ler kolesistokinin sekresyonunu artırırlar. Böylelikle n-3 PUFA'ların hem leptin hem de kolesistokinin hormonlarını etkileyerek iştah düzeylerini azalttığı, bunun sonucunda da vücut ağırlık kaybını desteklediği düşünülmektedir (1).

İnsülin direnci; obezite ve T2DM patogenezinin temelinde yer alan metabolik bir bozukluktur. Bu durum hem glikoneogenezi hem de lipogenezi artırır. Karaciğer, adipoz doku ve iskelet kası tarafindan üretilen fibroblast büyüme faktörü-21 (FGF-21)'in hem hepatik glukoz üretimini hem de plazma glukoz düzeylerini düşürdüğü, aynı zamanda insülin duyarlılığını ve adipositlere glukoz alımını artırdığı bilinmektedir (1). İnsanlar üzerinde yapılan bir çalışmada, obezitenin FGF-21 düzeylerini artırdığı ve bir dirence neden olduğu gösterilmiştir (31). Omega-3 PUFA'ların ise meydana gelen FGF-21 direncini azaltması sonucu insülin duyarlılığını artırdığı düşünülmektedir (1). Ek olarak, n-3 PUFA'lar hücre membranlarının fosfolipidlerine katılarak, hücre membran akışkanlığının değiştirilmesi yoluyla insülin 
reseptörlerinin ekspresyonunu, afinitesini ve sayısını artırdığı bildirilmektedir (32). Ayrıca, n-3 PUFA'lar glukoz taşıyıcı protein-4'ün (GLUT-4) ekspresyonunu artırmaktadır. İnsülin tarafından hücre membranına translokasyonu sağlanan GLUT-4'ler, iskelet kası ve adipoz dokuda glukoz taşıyıcısı olarak görev yaparlar (33). Tip 2 DM’li bireylere farklı miktar ve sürelerde n-3 PUFA desteği uygulanmış 26 randomize kontrollü çalışmanın değerlendirildiği bir meta-analizden elde edilen bulgulara göre, n-3 PUFA'ların insülin duyarlılığını artırdığı bildirilmiştir (13). Böylelikle, obezite ile ilişkili olan insülin direncinin önlenmesi ve azaltılması suretiyle, n-3 PUFA'ların obezite üzerinde olumlu etkilerinin olduğu düşünülmektedir (1).

Omega-3 PUFA'ların lipojenik ve glikolitik gen ekspresyonlarını baskıladığı, hem karaciğer hem de iskelet kasında yağ asidi oksidasyonunu artıran genleri aktive ettiği düşünülmektedir. Etki mekanizması ise transkripsiyon faktörleri olan karbonhidrat yanıt elementini bağlayan protein (carbohydrate responsive element binding protein, ChREBP) ve sterol düzenleyici eleman bağlayıcı protein-1 (sterol regulatory element binding protein-1, SREBP-1) üzerinden gerçekleşmektedir (1). Omega-3 PUFA'lar tarafindan ChREBP'nin aktivitesinin baskılanması, yağ asidi sentaz (FAS) ve pirüvat kinaz gibi lipojenik ve glikolitik gen ekspresyonlarını azalttığı gösterilmiştir (34). Ayrica SREBP-1 protein ekspresyonunun n-3 PUFA'lar tarafindan baskılanması, FAS ve asetil-KoA karboksilaz (ACC) gibi lipojenik gen ekspresyonlarının da azaltılmasına neden olduğu tespit edilmiştir (35). Bunların dışında n-3 PUFA'lar, peroksizom proliferatör aktive edici reseptörler (PPAR'lar) için ligand görevi görebilir. Birçok fonksiyona sahip olan PPAR'lar; özellikle adipogenez, lipid metabolizması,inflamasyon ve metabolik homeostazın sürdürülmesinde rol oynayan genlerin kontrolünde görev almaktadırlar. Memelilerde şimdiye kadar tanımlanan 3 farklı PPAR izoformlarından biri olan PPARa; karaciğer, böbrek, kalp ve kas gibi enerji gerektiren dokularda ifadelenmektedir. Enerji gereksinimi arttı̆̆ında bilhassa PPARa'nın aktivasyonu gerçekleşerek, yağ asidi katabolizması meydana gelmektedir. Bu durum oksidatif fosforilasyon yoluyla ATP üretimini sağlamaktadır. Omega-3 PUFA'ların PPAR'lar için ligand görevi görmesi sayesinde ise yağ asidi oksidasyonu artırılmaktadır (36).

Omega-3 PUFA'ları özellikle iskelet kası membranlarının fosfolipidlerine katılarak enerji harcamasını artırdığı düşünülmektedir. Toplam vücut kütlesinin önemli bir bölümünü oluşturan iskelet kası, dinlenme sırasındaki metabolik hızın yaklaşık olarak \%20'sinden sorumludur (37). İskelet kası membranlarının içeriğinde daha fazla n-3 PUFA'ların bulunması; membranlara bağlı proteinlerin aktivitesini değiştirerek, mitokondriyal proton sızıntısını veya protein sentezini artırarak enerji harcamasını etkilediği düşünülmektedir. Ancak, n-3 PUFA'ların belirtilen bu etkileri insanlar üzerinde yapılan çalışmalarda belirsizliğini korumaktadır. Sağlıklı yaşlı bireylere 12 hafta boyunca uygulanan 3 g/gün EPA ve DHA desteğinin; bireylerin dinlenme metabolik hızını (DMH) \%14, egzersiz sırasındaki enerji harcamasını \%10, dinlenme sirasındaki yağ oksidasyonunu \%19 ve egzersiz sırasındaki yağ oksidasyonunu \%27 oranında artırdığı tespit edilmiştir (38). Sağlıklı erkekler üzerinde yapılan bir çalışmada ise 12 hafta boyunca 2 g/gün EPA + 1 g/gün DHA desteğinin DMH’1 \%5.3 oranında artırdığı bulunmuştur. Ancak, vücut kütlesi dikkate alındığında bu etkilerinin istatistiksel olarak anlamlı olmadığı sonucuna varılmıştır. Ayrıca, n-3 PUFA'ların iskelet

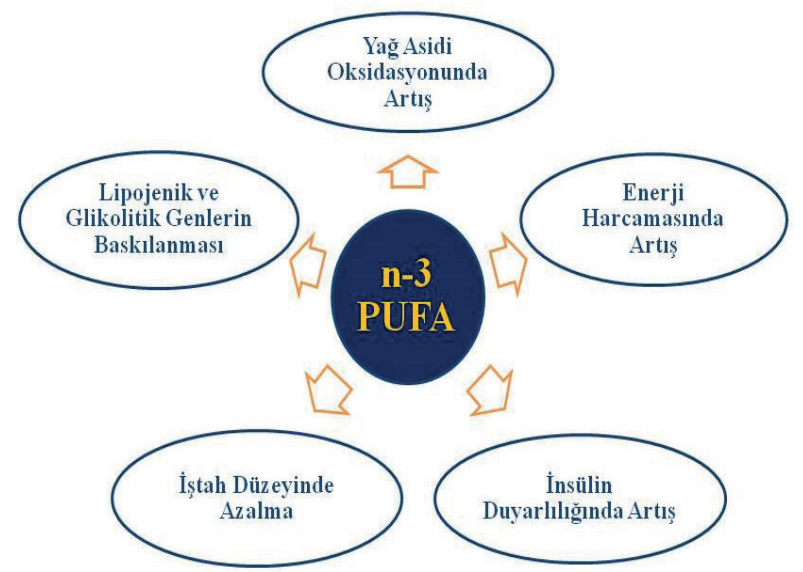

Şekil 2. Omega-3 PUFA'ların Olası Etki Mekanizmaları $(1,4,9)$ 
kası yağ metabolizmasında herhangi bir değişikliğe neden olmadığı tespit edilmiştir (39). Aynı doz ve süre ile EPA + DHA desteği uygulanan başka bir çalışmada da n-3 PUFA'ların, sağlıklı genç erkek bireylerde hem DMH'ı hem de yağ asidi oksidasyonunu etkilemediği bulunmuştur (40).

\section{SONUÇ VE ÖNERILER}

Dünya genelinde obezite prevalansında görülen ciddi düzeylerdeki artışlar, obezitenin pandemik bir hastalık olarak kabul edilmesine neden olmuştur. Tedavi edilemediği takdirde birçok metabolik bozukluğa neden olarak morbidite ve mortalite oranlarını artırabilmektedir. Tibbi beslenme tedavisi ile birlikte uygun egzersiz uygulamaları ve yaşam tarzı değişiklikleri birincil tedavi yöntemleri arasında yer almaktadır. Bu yöntemlere ek olarak vücut ağırlık kaybını destekleyici olması nedeniyle besin destekleri umut vericidir. Bu besin desteklerinden biri olan n-3 PUFA'lar ile ilgili literatürdeki çalışmalar incelendiğinde; alımlarının obezitede güvenilir olduğu, ancak vücut ağırlık yönetiminde tek başına etkili olamayacağı görülmektedir. Ayrıca, bu konu ile ilgili yapılan araştırmalarda diyette yer alan n-3 PUFA kaynaklarının değerlendirilmesi için genellikle subjektif yöntemlerin kullanıldığı ve yapılan klinik araştırma sayısının yetersiz olduğu dikkat çekmektedir. Ek olarak, çalışmalarda uygulanan n-3 dozu ve süresinin heterojen olmasindan dolayı optimal bir öneride bulunulamamaktadır. Gelecekte yapılacak olan araştırmaların özellikle n-3 indeksine yönelmesi, n-3 PUFA'ların vücut ağırlık yönetimindeki etkinliği hakkında daha kesin ve güvenilir bulguların elde edilmesini sağlayacaktır.

Yazarlık katkısı - Author contributions: Çalışmanın tasarımi: RMA, NZE; İlgili literatürün taranması: RMA, NZE; Makale taslağının oluşturulması: RMA; Içerik için eleştirel gözden geçirme RMA, NZE; Yayınlanacak versiyonun son onayl: RMA, NZE - Study design: RMA, NZE; Literature review: RMA, NZE; Draft preparation: RMA; Critical review for content: RMA, NZE; Final approval of the version to be published: RMA, NZE.
Çıkar çatışması - Conflict of interest: Yazarlar çıkar çatışması olmadığın beyan ederler. - The authors declare that they have no conflict of interest.

\section{KAYNAKLAR}

1. Albracht-Schulte K, Kalupahana NS, Ramalingam L, Wang S, Rahman SM, Robert-McComb J, et al. Omega-3 fatty acids in obesity and metabolic syndrome: A mechanistic update. J Nutr Biochem. 2018;58:1-16.

2. World Health Organization (WHO). Obesity and overweight. Apr 1, 2020. Available at: https://www. who.int/news-room/fact-sheets/detail/obesity-andoverweight. Accessed April 30, 2021.

3. T.C. Sağlık Bakanlığı Halk Sağlığı Genel Müdürlüğüu. Türkiye Beslenme ve Sağlık Araştırması (TBSA). T.C. Sağlık Bakanlığı Yayın No: 1132, Ankara 2019. Erişim: https://hsgm.saglik.gov.tr/depo/birimler/sagliklibeslenme-hareketli-hayat-db/Yayinlar/kitaplar/TBSA_ RAPOR_KITAP_20.08.pdf Erişim tarihi: 8 Haziran 2021.

4. Payahoo L, Ostadrahimi A, Farrin N, Khaje-Bishak Y. Effects of n-3 polyunsaturated fatty acid supplementation on serum leptin levels, appetite sensations, and intake of energy and macronutrients in obese people: A randomized clinical trial. J Diet Suppl. 2018;15(5):596-9.

5. Sala-Vila A, Guasch-Ferré M, Hu FB, Sánchez-Tainta A, Bulló M, Serra-Mir M, et al. Dietary a-linolenic acid, marine $\omega-3$ fatty acids, and mortality in a population with high fish consumption: Findings from the Prevención con Dieta Mediterránea (PREDIMED) study. J Am Heart Assoc. 2016;5(1):e002543.

6. Razny U, Kiec-Wilk B, Polus A, Goralska J, MalczewskaMalec M, Wnek D, et al. Effect of caloric restriction with or without n-3 polyunsaturated fatty acids on insulin sensitivity in obese subjects: A randomized placebo controlled trial. BBA Clin. 2015;4:7-6.

7. Thorsdottir I, Tomasson H, Gunnarsdottir I, Gisladottir E, Kiely M, Parra MD, et al. Randomized trial of weightloss-diets for young adults varying in fish and fish oil content. Int J Obes. 2007;31(10):1560-6.

8. Keshavarz SA, Mostafavi SA, Akhondzadeh S, Mohammadi MR, Hosseini S, Eshraghian MR, et al. Omega-3 supplementation effects on body weight and depression among dieter women with co-morbidity of depression and obesity compared with the placebo: A randomized clinical trial. Clin Nutr ESPEN. 2018;25:37-6.

9. DeFina LF, Marcoux LG, Devers SM, Cleaver JP, Willis BL. Effects of omega-3 supplementation in combination with diet and exercise on weight loss and body composition. Am J Clin Nutr. 2011;93(2):455-7. 
10. Tapsell LC, Batterham MJ, Charlton KE, Neale EP, Probst YC, O'Shea JE, et al. Foods, nutrients or whole diets: Effects of targeting fish and LCn3PUFA consumption in a 12mo weight loss trial. BMC Public Health. 2013;13:1231.

11. Simopoulos AP. An increase in the omega-6/omega-3 fatty acid ratio increases the risk for obesity. Nutrients. 2016;8(3):128.

12. Saini RK, Keum YS. Omega-3 and omega-6 polyunsaturated fatty acids: Dietary sources, metabolism, and significance-A review. Life Sci. 2018;203:255-13.

13. Song X, Tian S, Liu Y, Shan Y. Effects of Omega-3 PUFA Supplementation on insulin resistance and lipid metabolism in patients with T2DM: A systematic review and meta-analysis. Curr Dev Nutr. 2020;4(Suppl 2):77.

14. U.S. Food and Drug Administration. Qualified Health Claims: Letters of Enforcement Discretion. Omega-3 Fatty Acids. Sep 8, 2004. Available at: https://www. fda.gov/food/food-labeling-nutrition/qualified-healthclaims-letters-enforcement-discretion Accessed July 29, 2021.

15. EFSA Panel on Dietetic Products, Nutrition and Allergies (NDA). Scientific opinion on the tolerable upper intake level of eicosapentaenoic acid (EPA), docosahexaenoic acid (DHA) and docosapentaenoic acid (DPA). EFSA Journal. 2012;10(7):2815.

16. U.S. Department of Health and Human Services and U.S. Department of Agriculture. 2015-2020 Dietary Guidelines for Americans. 8 $^{\text {th }}$ Edition. Dec, 2015. Available at: http://health.gov/dietaryguidelines/2015/guidelines/ Accessed July 29, 2021.

17. Garaiova I, Guschina IA, Plummer SF, Tang J, Wang D, Plummer NT. A randomised cross-over trial in healthy adults indicating improved absorption of omega-3 fatty acids by pre-emulsification. Nutr J. 2007;6:4.

18. Schlesinger $S$, Neuenschwander $M$, Schwedhelm $C$, Hoffmann G, Bechthold A, Boeing H, et al. Food groups and risk of overweight, obesity, and weight gain: A systematic review and dose-response meta-analysis of prospective studies. Adv Nutr. 2019;10(2):205-13.

19. Lee $\mathrm{CH}, \mathrm{Fu} \mathrm{Y,} \mathrm{Yang} \mathrm{SJ,} \mathrm{Chi} \mathrm{CC.} \mathrm{Effects} \mathrm{of} \mathrm{omega-3}$ polyunsaturated fatty acid supplementation on nonalcoholic fatty liver: A systematic review and metaanalysis. Nutrients. 2020;12(9):2769.

20. Gunnarsdottir I, Tomasson H, Kiely M, Martinéz JA, Bandarra NM, Morais MG, et al. Inclusion of fish or fish oil in weight-loss diets for young adults: Effects on blood lipids. Int J Obes. 2008;32(7):1105-9.
21. Harden CJ, Dible VA, Russell JM, Garaiova I, Plummer SF, Barker ME, et al. Long-chain polyunsaturated fatty acid supplementation had no effect on body weight but reduced energy intake in overweight and obese women. Nutr Res. 2014;34(1):17-7.

22. Zhang YY, Liu W, Zhao TY, Tian HM. Efficacy of omega-3 polyunsaturated fatty acids supplementation in managing overweight and obesity: A meta-analysis of randomized clinical trials. J Nutr Heal Aging. 2017;21(2):187-5.

23. Du S, Jin J, Fang W, Su Q. Does fish oil have an antiobesity effect in overweight/obese adults? A metaanalysis of randomized controlled trials. PLoS One. 2015;10(11):e0142652.

24. Micallef M, Munro I, Phang M, Garg M. Plasma n-3 polyunsaturated fatty acids are negatively associated with obesity. Br J Nutr. 2009;102(9):1370-4.

25. Burrows T, Collins CE, Garg ML. Omega-3 index, obesity and insulin resistance in children. Int J Pediatr Obes. 2011;6(2-2):e532-9.

26. Ameur A, Enroth S, Johansson A, Zaboli G, Igl W, Johansson ACV, et al. Genetic adaptation of fatty-acid metabolism: A human-specific haplotype increasing the biosynthesis of long-chain omega-3 and omega- 6 fatty acids. Am J Hum Genet. 2012;90(5):809-11.

27. Huerta AE, Navas-Carretero S, Prieto-Hontoria PL, Martínez JA, Moreno-Aliaga MJ. Effects of a-lipoic acid and eicosapentaenoic acid in overweight and obese women during weight loss. Obesity. 2015;23(2):313-8.

28. Pérez-Matute P, Marti A, Martínez JA, Fernández-Otero MP, Stanhope KL, Havel PJ, et al. Eicosapentaenoic fatty acid increases leptin secretion from primary cultured rat adipocytes: Role of glucose metabolism. Am J Physiol Regul Integr Comp Physiol. 2005;288(6):R1682-8.

29. Pérez-Matute P, Pérez-Echarri N, Martínez JA, Marti A, Moreno-Aliaga MJ. Eicosapentaenoic acid actions on adiposity and insulin resistance in control and highfat-fed rats: Role of apoptosis, adiponectinand tumour necrosis factor-a. Br J Nutr. 2007;97(2):389-9.

30. Munro IA, Garg ML. Dietary supplementation with n-3 PUFA does not promote weight loss when combined with a very-low-energy diet. Br J Nutr. 2012;108(8):14668.

31. Zhang X, Yeung DCY, Karpisek M, Stejskal D, Zhou ZG, Liu F, et al. Serum FGF21 levels are increased in obesity and are independently associated with the metabolic syndrome in humans. Diabetes. 2008;57(5):1246-7.

32. Perona JS. Membrane lipid alterations in the metabolic syndrome and the role of dietary oils. Biochim Biophys Acta - Biomembr. 2017;1859(9):1690-13. 
33. Zayed EA, AinShoka AA, El Shazly KA, Abd El Latif HA. Improvement of insulin resistance via increase of GLUT4 and PPARy in metabolic syndrome-induced rats treated with omega-3 fatty acid or l-carnitine. J Biochem Mol Toxicol. 2018;32(11):e22218.

34. Dentin R, Benhamed F, Pégorier JP, Foufelle F, Viollet $B$, Vaulont $S$, et al. Polyunsaturated fatty acids suppress glycolytic and lipogenic genes through the inhibition of ChREBP nuclear protein translocation. J Clin Invest. 2005;115(10):2843-11.

35. Yahagi N, Shimano H, Hasty AH, Amemiya-Kudo M, Okazaki H, Tamura Y, et al. A crucial role of sterol regulatory element-binding protein-1 in the regulation of lipogenic gene expression by polyunsaturated fatty acids. J Biol Chem. 1999;274(50):35840-4.

36. Botta M, Audano M, Sahebkar A, Sirtori CR, Mitro N, Ruscica M. PPAR agonists and metabolic syndrome: An established role? Int J Mol Sci. 2018;19(4):1197.

37. Zurlo F, Larson K, Bogardus C, Ravussin E. Skeletal muscle metabolism is a major determinant of resting energy expenditure. J Clin Invest. 1990;86(5):1423-7.

38. Logan SL, Spriet LL. Omega-3 fatty acid supplementation for 12 weeks increases resting and exercise metabolic rate in healthy community - dwelling older females. PLoS One. 2015;10(12):e0144828.

39. Gerling CJ, Whitfield J, Mukai K, Spriet LL. Variable effects of 12 weeks of omega- 3 supplementation on resting skeletal muscle metabolism. Appl Physiol Nutr Metab. 2014;39(9):1083-8.

40. Jannas-Vela S, Roke K, Boville S, Mutch DM, Spriet LL. Lack of effects of fish oil supplementation for 12 weeks on resting metabolic rate and substrate oxidation in healthy young men: A randomized controlled trial. PloS One. 2017;12(2):e0172576. 